\title{
Research on the Application of Financial Technology to SME in Shaanxi Province
}

\author{
Yiyuan Huang \\ School of Business, Institute for Corporate Social Responsibility, Xi'an Siyuan University \\ Xi'an, China
}

\begin{abstract}
The financing difficulties of SME in Shaanxi are mainly due to their narrow financing channels. Financial technology plays an essential role in promoting China's economic development, especially in alleviating the financing difficulties of SME in Shaanxi Province. However, the government has always adopted a policy of restraining Financial technology. The elaboration of the supplementary role of private financing in the People's Bank of China's Regional Financial Operation Report 2004 indicates the coming of the legal era for private funding. Based on this, this paper attempts to use financial technology to solve the financing problems of SMEs in Shaanxi. Based on the analysis of the financing status of SME in Shaanxi Province and the introduction of the development status and characteristics of Financial technology, this paper makes a demand analysis and advantage analysis on the financing problems of SME using economic science and technology, and makes rational thinking on the financing of SME using economic science and technology, and fully understands the basis of business science and technology risks. On the other hand, it puts forward some policy suggestions on Financial technology to support the financing of SMEs in Shaanxi, to guide the legalization of economic science and technology, and to better serve the financing of SMEs in Shaanxi.
\end{abstract}

\section{Keywords-financing technology; SMEs; Shaanxi; finance}

\section{INTRODUCTION}

Since the reform and opening-up, China's economic development momentum is rapid, and the contribution of SME to China's economic growth can be said to be indispensable. Especially in technological innovation, the dynamic market economy is solving urban and rural employment, promoting social harmony and stability. However, the development of SME is stagnating because of the difficulty of financing. SME (SMEs) are weak in strength, small in scale, and poor in risk resistance. These factors make commercial banks prefer large enterprises, while SMEs seldom pay attention to them. Although the state has issued many corresponding policies, such as encouraging commercial banks to provide loans to SMEs and setting up GEM market, these policies are far from meeting the needs of many SMEs, especially after the financial crisis. Therefore, financing difficulties have become an essential factor in restricting the development of SME.

\section{RESEARCH SIGNIFICANCE}

In practice, it is economic science and technology that has always supported the development of SMEs in finance. Until today, private financing is still a vital financing channel for SMEs. International experience shows that Financial technology play an essential role in solving the financing problems of SMEs in Shaanxi Province. However, the Chinese government believes that economic science and technology are illegal, and it has always adopted a policy of restraint and has never given it legal status. There are indeed some risks in Financial technology. Developing economic science and technology will not only affect the government's macro-control activities but also cause some pressure on commercial banks in competition. Besides, it will also bring some unstable factors to society, which is why the state restrains it. However, everything has two sides. Since it has a negative side, it will undoubtedly have a positive side. We cannot ignore its decisive role. We know that most of the private financing activities are not in conformity with the existing laws and regulations, but it is not legal and unreasonable to draw an equal sign. In solving the financing problem of SME in Shaanxi, the contribution of Financial technology is enormous. Therefore, it is essential to study the role of economic science and technology in solving the financing problems of SMEs in Shaanxi.

\section{FINANCING Status OF SME IN ShaANXI PROVINCE}

\section{A. The channel of endogenous financing is not smooth.}

Low cost and high income are the advantages of funding endogenous; because of this, enterprises will regard it as an essential financing channel. Compared with developed countries, China's SMEs are subject to many restrictions on internal financing. According to relevant surveys, self-owned funds, bank loans, and private loans account for about 35\%, 35\% and $30 \%$ of the total funds of Wenzhou SMEs, respectively. This is still in the eastern region, the more westward it goes, and the worse it will be. Take Liuyang City in Hunan Province for example, and bank loans account for about $80 \%$ of the total enterprise financing. On the whole, the proportion of SMEs in internal funding in different regions is quite different, but compared with developed countries, the percentage of SMEs in financing is relatively low.

\section{B. External financing channels are narrow.}

Since 1979, China's financial market has been continually improving. The trend of enterprises' financing channels is that the financing channels become more diversified, the sources become more socialized, and the behaviors become more market-oriented. Generally speaking, SMEs are still very single in financing channels, and the overall financing model relies too much on bank loans. 


\section{AnAlysis ON THE CAUSES OF FinANCING DIFFICULTIES OF SME IN SHAANXI PROVINCE}

From the study of the current situation of SMEs financing in Shaanxi Province, we can see that SMEs are facing more and more prominent difficulties in financing. The core problem that restricts the development of SME is financing. Two reasons hinder the growth of SME: internal and external factors.

\section{A. The quality of SMEs themselves is not high, and the internal governance structure is not perfect}

At the beginning of its establishment, most SME tends to adopt two modes in their business models, individual investment, or partnership. In the SME of the partnership model, the partners bear joint and several liabilities, therefore, if the property and health of the partnership changes, the stability of the partnership will be caused. Even if the nature of the enterprise is a limited liability company, the above problems can be avoided. However, as we all know, most SME is family-based; that is to say, the decision-making power of enterprises is in one hand, so the corporate governance structure is very irregular.

SME has insufficient credit and poor mortgage guarantee ability. The market economy is a credit economy in a sense. Credit has become an essential criterion of market transactions. But at present, the social credit system of our country is still not perfect, and the credit concept of economic subjects, including SME, is weak so that the healthy credit relationship is distorted. According to the statistics of the State Administration of Industry and Commerce, the losses caused by contract fraud, poor quality and counterfeiting, increased triangular debts and cash transactions are about 5.5 billion Yuan, 19 billion Yuan, and 190 billion Yuan, respectively. Many enterprises here are SME. The lack of credit for SME has become a significant factor in the difficulty of bank loans. To avoid credit risk, banks usually require loan enterprises to provide collateral or guarantee. However, SME does not have much-fixed assets because of their small scale of operation. Even if they have fixed assets, they are also some broken factories and equipment, which makes mortgage difficult.

\section{B. China's financial system is not sound}

China has a highly centralized banking system and weak small and medium-sized financial institutions, private capital cannot be included in the central part of the banking system, indirect financing is also tricky, and the direct financing channels are strictly restricted, and China's capital market does not have many levels. State-owned banks are still the leading financial institutions in China, holding no less than $95 \%$ of bank funds, and state-owned banks are always more inclined to lend to state-owned enterprises and large enterprises. Because SMEs are neither large-scale enterprises nor state-owned enterprises, and their financing model is very disadvantageous to them. Now let's look at small and medium-sized banks and Financial technology institutions. They have the following characteristics: small scale, weak asset strength, weak ability to withstand risks, low number and administrative control of business operations, so they cannot enjoy the treatment enjoyed by state-owned banks. Besides, private capital is difficult to be classified into the banking system, even if it enters, it will be subject to administrative control, and it cannot be operated according to market standards.

\section{ADVANTAGES OF FINANCIAL TECHNOLOGY IN SOLVING FINANCING DIFFICULTIES OF SME IN SHAANXI PROVINCE}

\section{A. Information advantages}

It can be reflected in two aspects: first, because the lender knows all aspects of the borrower's information, it can better distinguish the borrower's repayment ability, so that credit risk can be reduced or avoided; second, the lender can effectively monitor the loan situation, mainly because the borrower and borrower have a special interpersonal relationship.

\section{B. Guarantee advantages}

Financial technology can use real estate and land as guarantee for loans, which are not available in formal finance; besides, it also has social guarantee mechanism, which is because both sides of financial technology borrowing and lending are basically relatives and friends, and this trust relationship has a robust social restraint capacity, so this guarantee mechanism. Sometimes it is also called invisible guarantee mechanism.

\section{Cost advantages}

Financial technology have strong rationality. Township is the principal gathering place of economic science and technology organizations. Township enterprises are the main object of lending. It helps lenders to judge the repayment status of borrowers so that that information asymmetry can be reduced or even avoided, and information opacity barriers of enterprises can be effectively solved. This is precisely what formal finance can't do.

\section{Policy SugGeStions ON FinANCIAL TECHNOLOGY SuPPORTING FinANCING OF SME IN SHAANXI PROVINCE}

\section{A. Regulating Financial technology and Strengthening Supervision}

Relevant laws and regulations should be established and perfected, and their legal status should be given. Necessarily, China's current law does not restrict and enforce it. The suggestions given by the author in this paper make it possible to amend or abolish those laws which are not conducive to the development of Financial technology and which do not conform to the reality of China. At the same time, relevant laws and regulations should be established and perfected so that the distinction between formal and non-illegal finance can be defined from a legal point of view. If Financial technology have reasonable and legitimate purposes and interest rates are not divorced from the given scope, such economic science and technology should determine its legal status in law, rather than in code. The financing activities referred to in legitimate financing should be fraudulent and money laundering activities aimed at illegal possession. For the development of Financial technology, the government should adopt the method of combining guidance and promotion.

According to the relevant laws, the CBRC should supervise its implementation to regularize the development of Financial technology. Besides, the illegal activities in economic science and technology should be strictly and timely banned to make 
the business market fairer in competition. Here we take Wenzhou as an example. There are two main ways for private capital to increase its value. One is to invest in the stock market, and the other is to invest in the real estate market. However, the current stock market is depressed, and the government also suppresses the real estate market. In this case, most of the private capital has been withdrawn and idle. If the government can timely formulate relevant policies to give active guidance to private equity, then the financing problem of SMEs can be well solved.

At present, there is no perfect social credit system in China. There are severe information asymmetry and lack of financing channels in SME. According to this situation, it is necessary to develop relationship financing. Illegal financial institutions generally exist in the developed eastern regions, such as usury and private banking, which have been severely cracked down by the government but cannot be eradicated. This shows that the financing mode urgently needed by our country should meet the development needs of the private economy, and this demand is precisely what relationship financing can meet. Therefore, the state should promote and develop relationship financing according to China's current situation, to better serve China's economy.

\section{B. Active and Effective Development of Microfinance Companies}

As a hotspot rising recently, the existence and development of microfinance companies are of considerable significance to China's financial market. Microfinance companies can become a link between large financial institutions and small enterprises and truly improve our economic system. At the same time, because the service object of microfinance companies is clearly for small companies, it can provide similar financial services for many SME, and offer a new way for the financing of SME in Shaanxi Province, thus alleviating the financing difficulties of SME in Shaanxi Province.

\section{Enhancing the Credit Image of SME}

If the virtual economy cannot be adequately supported by industry, then the economy is like a castle in the air. Therefore, we should accelerate the upgrading and innovation of our industry and not wait for funds blindly. This is because funds can only solve the current problems of enterprises, but cannot create long-term operational effects. Only by upgrading their industries and innovating in real-time can enterprises genuinely integrate into the current economic development wave, so that the government will give more preferential policies. At the same time, SME should also conduct more market research, pay attention to marketing management, so that they can formulate business projects according to market demand, to enhance economic efficiency. Enterprise management should be scientific and continuously improve the management system and various incentive mechanisms so that production efficiency can be effectively improved. To improve the repayment ability and get financing smoothly, enterprises must improve their profitability.

We should pay close attention to the role of Financial technology in the development of enterprises. For the development of enterprises, senior leaders should make long-term plans, and the current economic environment should formulate the near-term strategies. Through the investigation, it is not difficult to find that some enterprises are blind in the expansion of the business chain, which makes the daily turnover of funds difficult, and thus makes business activities unable to proceed normally. Therefore, enterprises should not only plan the utilization and repayment of loans but also design the overall situation, to be more conducive to the development of enterprises.

\section{CONCLUSION}

Private financing has become an essential part of social funding. Faced with the vigorous development of private funding, government departments should not ignore the existence of private funding. They should conduct objective research and analysis and make timely policy adjustments. Facing the considerable scale of Financial technology and the difficulty of the funding in the non-public economy, the state should adjust its policy orientation in time.

The market order in the financial market should be continuously improved so as to rationalize the flow of non-governmental funds and crack down severely on illegal financing activities, so that unlawful elements cannot borrow non-governmental loans to engage in fraud and money laundering and other events; increase public opinion propaganda efforts to raise people's awareness of financial risks.

For non-governmental financing, we should step up monitoring and guidance, and establish a relevant monitoring system, so that the tracking of Financial technology can be systematic, scientific, and standardized. To make the monitoring more representative and accurate, the people's bank at the grass-roots level collects relevant data regularly.

\section{ACKNOWLEDGMENTS}

This work is sponsored by the research project of "Special scientific research project" by Education Department of Shaanxi Provincial Government. Project No.: 19JK0676.

\section{REFERENCES}

[1] Aidong Wang. An empirical study on the relationship between China's financial development and economic growth based on sensor technology[J]. EURASIP Journal on Wireless Communications and Networking,2019,2019(1).

[2] Tao Luo. Research on financial network big data processing technology based on fireworks algorithm[J]. EURASIP Journal on Wireless Communications and Networking,2019,2019(1).

[3] Feng Xiong, Larelle Chapple, Si Xu, Wenwei Lin. Adoption and use of technology with low litigation risk - the case of financial reporting on Twitter by ASX companies[J]. Technology Analysis \& Strategic Management,2019,31(10).

[4] Lawrence Green, Ming-Chien Sung, Tiejun Ma, Johnnie E. V. Johnson. To what extent can new web-based technology improve forecasts? Assessing the economic value of information derived from Virtual Globes and its rate of diffusion in the financial market[J]. European Journal of Operational Research,2019,278(1).

[5] Miao Zhang, Juanjuan Yang. Research on Financial Technology and Inclusive Finance Development[P]. Proceedings of the 2018 6th International Education, Economics, Social Science, Arts, Sports and Management Engineering Conference (IEESASM 2018),2019. 
[6] Jacob Donald Tan, John Tampil Purba, Andree E. Widjaya. Financial Technology as an Innovation Strategy for Digital Payment Services in the Millenial Generation[P]. Proceedings of the 1st Aceh Global Conference (AGC 2018),2019.

[7] Ya-Ning Li, Yang Lu, Hai-Ying Wang, Dong-Mei An. Which is More Advantageous in Financial Technology and Traditional Finance? Evidence from JD Finance[P]. Proceedings of the 6th International Conference on Management Science and Management Innovation (MSMI 2019),2019.

[8] Xinyi Wang. The Enlightenment of Technology Overtaking the Country to China\&apos;s Financial Support for Science and Technology Innovation[P]. Proceedings of the 2019 4th International Conference on Financial Innovation and Economic Development (ICFIED 2019),2019.

[9] Denies Priantinah, Mimin Nur Aisyah, Yavida Purim. The Analysis of Technology Acceptance Model (TAM) For Personal Financial Management On Mobile Application Technology[P]. Proceedings of the International Conference on Banking, Accounting, Management, and Economics (ICOBAME 2018),2019.

[10] Egi Arvian Firmansyah, Mohamad Anwar. ISLAMIC FINANCIAL TECHNOLOGY (FINTECH): ITS CHALLENGES AND PROSPECT[P]. Proceedings of the Achieving and Sustaining SDGs 2018 Conference: Harnessing the Power of Frontier Technology to Achieve the Sustainable Development Goals (ASSDG 2018),2019. 